\title{
Numerical evaluation of core concrete quality on the response of concrete jacketed columns
}

\section{Evaluación numérica de la calidad del concreto del núcleo en la respuesta de las columnas de concreto con cubierta}

Naci Caglar (Main and Corresponding Author)

Sakarya University, Engineering Faculty, Department of Civil Engineering

54187 Sakarya (Turkey)

caglar@sakarya.edu.tr

Halil Sezen

The Ohio State University, Department of Civil, Environment, and Geodetic Engineering

Columbus, OH 43210 (USA)

sezen.1@osu.edu

Muhammed Nadir Olabi

Sakarya University, Engineering Faculty, Department of Civil Engineering

54187 Sakarya (Turkey)

mhd.alolaby@ogr.sakarya.edu.tr

Manuscript Code: 1299

Date of Acceptance/Reception: 02.08.2019/18.01.2019

DOI: 10.7764/RDLC.18.2.301

\begin{abstract}
Reinforced concrete jacketing is one of the most frequently used methods for strengthening of reinforced concrete (RC) columns. A large number of experimental studies have been carried out to investigate the effectiveness of repair and strengthening techniques and interface treatment on the response of concrete jacketed columns. However, the effects of potential damage in existing column and quality of core concrete on the response of jacketed RC columns have not been investigated. One of the main goals of this study is to examine how the material properties of the existing column affect the overall response of the jacketed RC columns. Two computer models were developed and nonlinear analyses were performed to determine the moment-curvature relationships and axial load-moment interaction diagrams of concrete jacketed RC cross sections. The effects of material strength and magnitude of axial loads were investigated. It is determined that the strength of core concrete has no effect on the response of concrete jacketed RC columns under lower axial loads while it increases the strength and reduces the ductility under higher axial load levels.
\end{abstract}

Keywords: Strengthened columns, concrete jacketing, core concrete quality, reinforced concrete, moment-curvature.

Resumen

El revestimiento de hormigón armado es uno de los métodos más utilizados para reforzar las columnas de hormigón armado (RC). Se han Ilevado a cabo una gran cantidad de estudios experimentales para investigar la efectividad de las técnicas de reparación y fortalecimiento, y el tratamiento de la interfaz en la respuesta de columnas encamisadas de concreto. Sin embargo, no se han investigado los efectos del daño potencial en la columna existente y la calidad del concreto del núcleo en la respuesta de las columnas RC encamisadas. Uno de los objetivos principales de este estudio es examinar cómo las propiedades del material de la columna existente afectan la respuesta general de las columnas RC encamisadas. Se desarrollaron dos modelos de computadora y se realizaron análisis no lineales para determinar la relación entre el momento y la curvatura de las secciones transversales de RC encamisadas de concreto. Se investigaron los efectos de la resistencia del material y la magnitud de las cargas axiales. Se determina que la resistencia del núcleo de hormigón no afecta la respuesta de la columna RC con camisa de concreto bajo cargas axiales más bajas, mientras que aumenta la resistencia y reduce la ductilidad en niveles de carga axial más altos.

Recent major earthquakes caused significant casualties and severe damage to many buildings, which were designed according to older codes, as observed after the April 2009 L'Aquila (Italy), August 1999 Izmit (Turkey) and September 1999 Athens (Greece) earthquakes. These earthquakes have revealed the vulnerability of older reinforced concrete (RC) buildings and their columns. Some of the important structural deficiencies included low-quality concrete, poor confinement of the potential inelastic regions of members, weak column-strong beam behavior, short column behavior, inadequate splice lengths, and improper hooks of transverse reinforcement (Lekkas, 2001; Sezen et al., 2003; Elenas, 2003; Kawashima et al., 2010; Sarnoa et al., 2011; Celebi et al., 2013). Most of the older RC buildings have been designed to resist mainly gravity loads or much lower earthquake loads than the current expected seism design loads. Thus, they 
cannot provide the required ductility, lateral stiffness and strength as required by the current seismic design codes. These RC buildings should be strengthened because they are vulnerable to collapse in future earthquakes.

Different jacketing procedures are used as the main solution to strengthen RC columns in existing and older buildings. Various jacketing methods such as steel jacket (Nakahara \& Yin, 2018; Chai et al., 1991), concrete jacket (Thermou et al., 2014; Rupp et al., 2014), Fiber Reinforced Polymers (FRP) (Juntanalikit et al., 2016; Hosseini, et al., 2005), and high performance fiber reinforced concrete (HPFRC) jacketing (Di Carlo et al., 2017) have been studied to investigate the strengthening techniques effects on the behavior of RC columns under earthquake loads.

\section{Research Significance}

Concrete jacketing is one of the most commonly used methods to strengthen older RC buildings which do not meet the seismic design requirements of current codes. New and higher quality reinforced concrete placed around the existing column, or concrete jacket, provides confinement to the existing weaker concrete. As a result, the strength and ductility of the existing concrete increase, and in turn, stiffness, strength and ductility of the structural member and the structural system improve.

A large number of numerical and experimental studies have been carried out to investigate the effectiveness of repair and strengthening techniques, and interface treatment on the response of concrete jacketed RC columns (Achillopoulou, 2017; Di Carlo et al., 2017; Chaulagain et al., 2015; Thermou et al., 2014; Júlio \& Branco, 2008; Vandoros \& Dritsos, 2008; Sezen \& Miller, 2007; Bousias et al., 2007; Thermou et al., 2007; Rodriguez \& Park, 1994; Ersoy et al., 1993). Concrete with a low compressive strength of approximately 10-16 MPa was used in many older RC buildings (Elenas, 2003; Kawashima et al., 2010; Celebi et al., 2013). However, the effect of concrete quality of existing column or core concrete on the response of jacketed column has not been investigated. The main goal of this study is to examine how the core concrete quality and axial load level affect flexural performance of the concrete jacketed RC columns. The lateral and axial loads on the column can be due to man-made or natural hazards such as earthquakes. For this purpose, nonlinear analyses of three types of concrete jacketed RC columns are performed for different core concrete properties and axial load magnitudes. In this study, the axial load was assumed to be applied on the entire cross section of the strengthened reinforced column, including both core and jacket concrete.

State of the Art

\section{Fully confined concrete behavior}

The cross section of concrete jacketed RC columns can have three distinct confinement regions depending on the provided degree of confinement. New or jacketing concrete includes concrete cover, which is completely unconfined and called "Unconfined" concrete (Figure 1). Then concrete inside the jacket between the existing column and ties inside the jacket is called "Partially confined" concrete. The entire cross section of the existing column has now better confinement provided by the concrete jacket and transverse steel with 135-degree hooks inside the jacket. In this research, the entire existing column cross section is assumed confined by the new jacket and is called "Fully confined" concrete (Figure 1).

Figure 1. (a) Cross section and (b) Concrete material models for concrete jacketed RC columns. (Self-Elaboration).

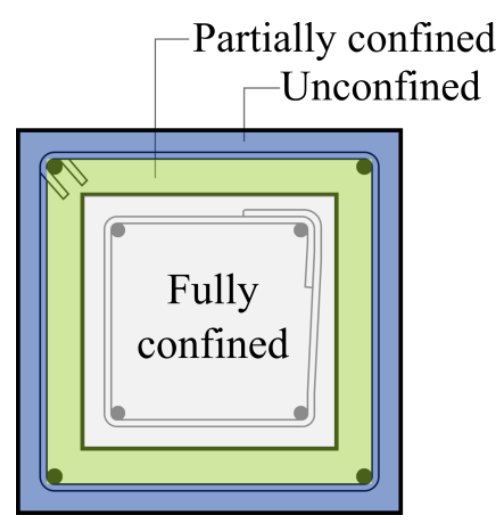

(a)

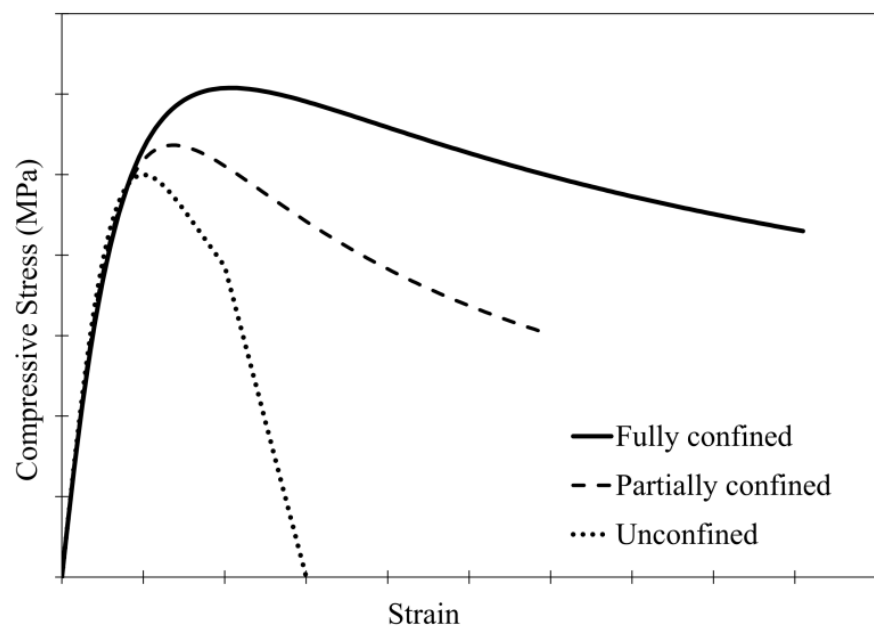

(b) 
In this study, "Unconfined" and "Partially confined" concretes were modeled with the material model developed by Mander et al. (1988). "Fully confined" concrete was modeled by using the material model developed by Campione et al. (2014). The model proposed by Campione et al. takes into account the effect of the poorly detailed transverse reinforcement in the core or existing column as well as transverse steel inside the jacket of the retrofitted RC column. However, the effects of slip at the interface of old and new concrete, shrinkage, and slipping of bars are not considered in this model for simplification.

The material model by Mander et al. (1988) relates the stress $\left(f_{c}\right)$ and strains $\left(\varepsilon_{c}\right)$ of the confined and unconfined concrete with Equation (1).

$$
f_{c}=\frac{f_{c c}^{\prime} \frac{\varepsilon_{c}}{\varepsilon_{c c}} r}{r-1+\left(\frac{\varepsilon_{c}}{\varepsilon_{c c}}\right)^{r}}
$$

where $r=E_{c} /\left(E_{c}-E_{s e c}\right)$, with $E_{c}=4700 \sqrt{f_{c o}^{\prime}}$ (in $\mathrm{MPa}$ ) and $E_{s e c}=f_{c c}^{\prime} / \varepsilon_{c c} \cdot f_{c c}^{\prime}$ and $\varepsilon_{c c}$ are maximum strength and corresponding strain of confined concrete calculated from Equations (2) and (3).

$$
\begin{aligned}
& f_{c c}^{\prime}=f_{c o}^{\prime}\left[2.254 \sqrt{1+\frac{7.94 f_{l}}{f_{c o}^{\prime}}}-2 \frac{f_{l}}{f_{c o}^{\prime}}-1.254\right] \\
& \varepsilon_{c c}=\varepsilon_{c o}\left[1+5\left(\frac{f_{c c}^{\prime}}{f_{c o}^{\prime}}-1\right)\right]
\end{aligned}
$$

where $f_{c o}^{\prime}$ and $\varepsilon_{c o}$ are maximum strength of unconfined concrete and corresponding strain, respectively. The lateral confinement pressure $\left(f_{l}\right)$ in the section is calculated from equilibrium of forces as shown in Figure 2 (Campione et al., 2014). In this paper, the lateral confinement is calculated by considering the contributions of poorly detailed column ties (with 90-degree hooks) in the existing column and the seismically detailed transverse steel (with 135-degree hooks) inside the jacket.

$$
f_{l, \text { core }}=f_{l, c} k_{p c} k_{v c}+f_{l, j} k_{e j} k_{v j}
$$

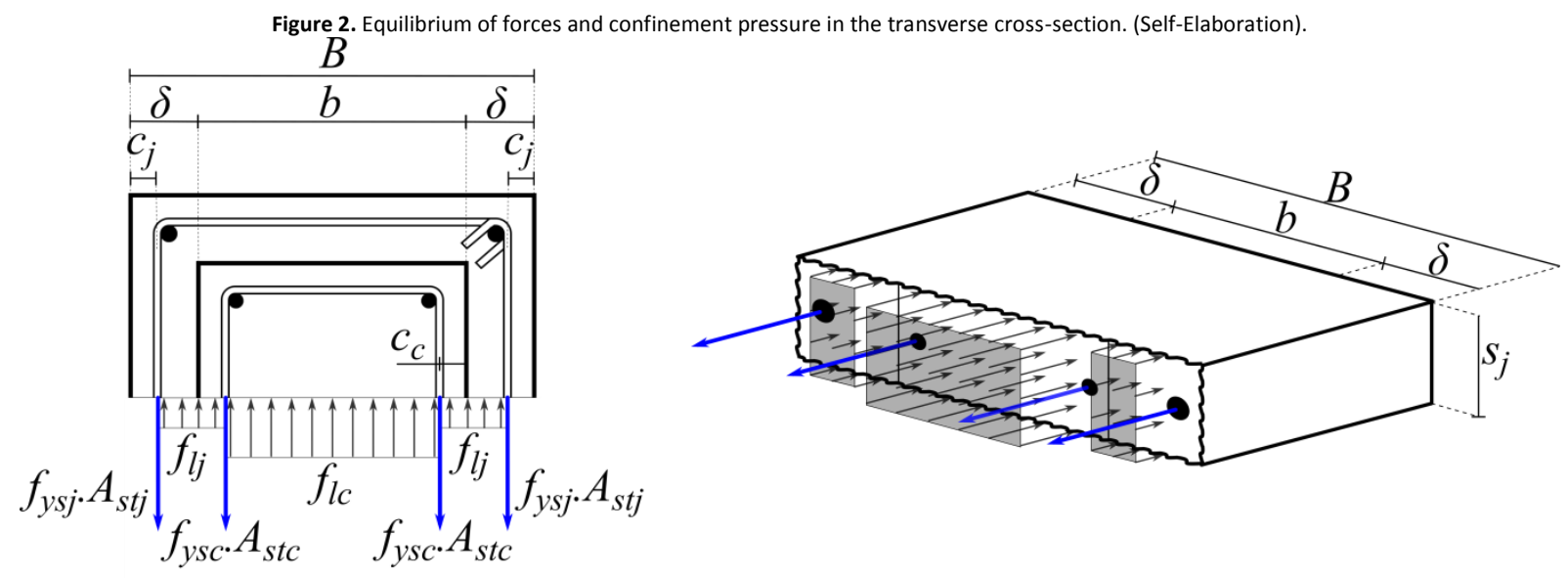

In Equation (4), the lateral confinement stresses from existing and jacket reinforcement $\left(f_{l, c}\right.$ and $\left.f_{l, j}\right)$ are modified by coefficients to account for the non-uniformity of the confinement pressure in the plane and elevation sides. From equilibrium of forces in the transverse direction, confinement stresses can be calculated as:

$$
\begin{aligned}
f_{l, c} & =\frac{2 f_{y s c} A_{s t c}}{\left(b-c_{c}\right) s_{c}} \\
f_{l, j} & =\frac{2 \cdot f_{y s j} A_{s t j}}{(B-\delta) s_{j}}
\end{aligned}
$$

where $b$ is width of the existing column and $B$ is width of the jacketed column. $f_{y s c}, A_{s t c}, s_{c}$, and $c_{c}$ are yield strength and area of existing column ties, vertical distance between ties, and concrete cover in the existing column cross section, 
respectively. $f_{y s j}, A_{s t j}, s_{j}$, and $c_{j}$ are yield strength and area of ties inside jacket, vertical distance between ties, and concrete cover in the external jacket, respectively. $\delta$, is the thickness of the external jacket.

From Campione et al. (2014), modification coefficients are calculated for the effect of internal ties in plane $\left(k_{p c}\right)$ and in elevation $\left(k_{v c}\right)$ as:

$$
\begin{aligned}
& k_{p c}=1-\frac{4}{6} \frac{\left(b-2 c_{c}-2 d_{b c}\right)^{2}}{\left(b-2 c_{c}\right)^{2}} \\
& k_{v c}=\left(1-\frac{s_{c}}{2\left(b-c_{c}\right)}\right)^{2}
\end{aligned}
$$

where $d_{b c}$ is diameter of longitudinal bar in the core column. Also, effect of external ties in plane $\left(k_{e j}\right)$ and in elevation $\left(k_{v j}\right)$ is calculated as:

$$
\begin{aligned}
& k_{e j}=1-\frac{2}{3 b^{2}} \sqrt{\left(b+2 c_{j}-2 \delta\right)^{3}} \sqrt{b-2 c_{j}+2 \delta} \\
& k_{v j}=\left(1-\frac{s_{j}}{2\left(b+2 \delta-2 c_{j}\right)}\right)^{2}
\end{aligned}
$$

The ultimate strain of the confined concrete $\left(\varepsilon_{c u}\right)$ was calculated using Equation (8) with considering the effects of the internal and the external transverse steel.

$$
\varepsilon_{c u}=0.004+\frac{1.4}{f_{c c}}\left[\frac{f_{y c} \varepsilon_{s u c} A_{s c}}{\left(b-c_{c}\right) s_{c}}+\frac{f_{y j} \varepsilon_{s u j} A_{s j}}{(B-\delta) s_{j}}\right]
$$

where $f_{y c}, A_{s c}, \varepsilon_{s u c}$ are yield strength of longitudinal steel, area of longitudinal steel bars, ultimate strain of longitudinal steel in the core section, respectively. $f_{y j}, A_{s j}, \varepsilon_{s u j}$ are yield strength of longitudinal steel, area of longitudinal steel bars, ultimate strain of longitudinal steel in the external jacket, respectively (Campione et al. 2014).

Methodology

\section{Model development and validation}

A new computer code is developed in Matlab (2011) to model the material properties of unconfined, partially confined and fully confined concrete in the column cross section (Figure 1b). The computer program is also used to determine axial load-moment interaction diagram of concrete jacketed RC columns.

Moment-curvature analysis is carried out using a uniaxial fiber model of the concrete jacketed RC columns. The analysis was carried out by using the Bernoulli assumption that plane sections remain plane under imposed axial load and moment actions. The cross section was discretized into multiple axial fibers. A linear strain distribution was imposed and the stress in each fiber was based on the uniaxial stress-strain relations for the material of that fiber, with the strain defined at the centroid of that fiber. The strain distribution was iterated until equilibrium was achieved under imposed moment and axial forces.

Specimen SBR is selected from literature (Ersoy et al., 1993) to compare the experimental data and numerical simulations of the concrete jacketed RC columns (Figure 3). In specimen SBR, the concrete compressive strengths were 40.3 $\mathrm{MPa}$ and $33.0 \mathrm{MPa}$ in the original $160 \mathrm{~mm}$ square column and inside the concrete jacket, respectively.

Sectional analysis was carried out using the open-source software OpenSees (McKenna et al., 2004), and a model was developed based on the computed material properties of unconfined, partially confined and fully confined concrete in the Matlab code (2011). The moment-curvature analysis results from Matlab and OpenSees models are compared with the experimental data from Ersoy et al. (1993) to validate the material models and the developed code (Figure 3c). Numerical results and experimental data show very good agreement and the model could simulate the response of the concrete jacketed RC column SBR relatively closely. 


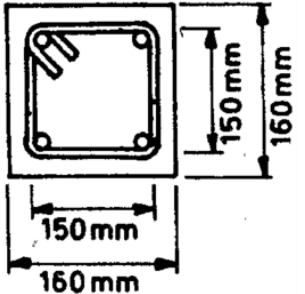

(a)

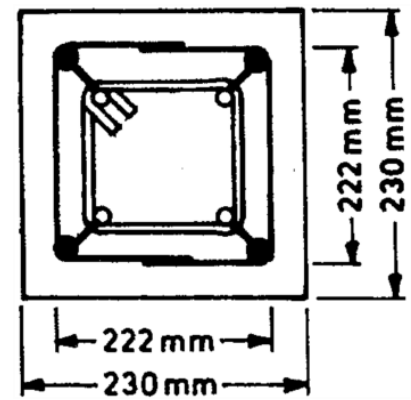

(b)

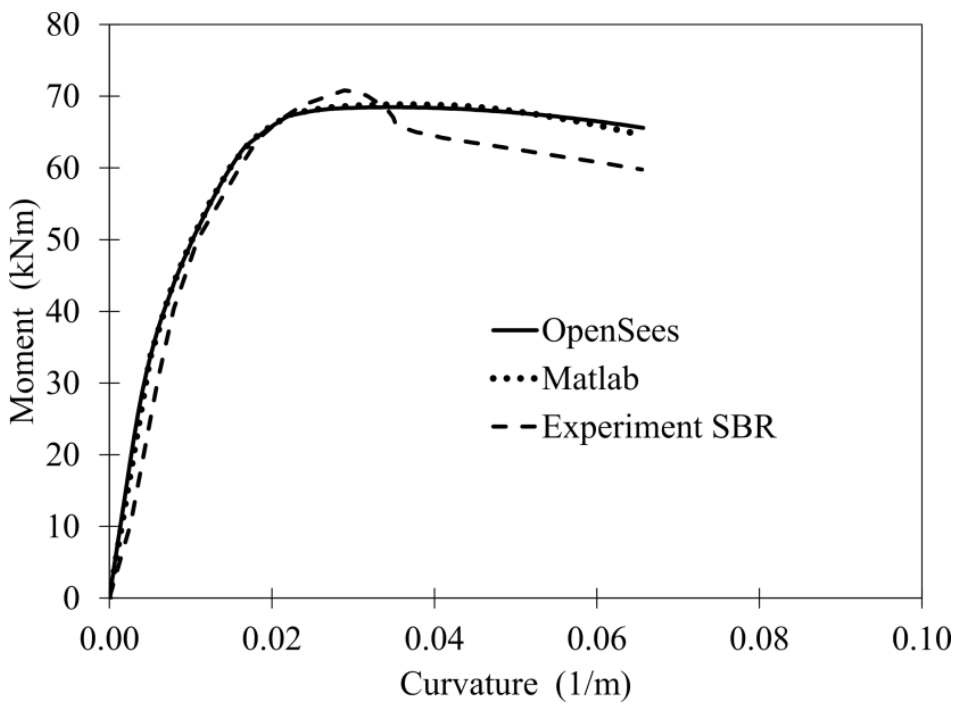

(c)

\section{Parametric Analysis}

In this study, a parametric study is performed to examine the effect of core concrete quality on the total lateral response of the concrete jacketed RC columns. The behavior of a concrete jacketed RC column is calculated by using OpenSees (McKenna et al., 2004). In OpenSees, cross sectional models of concrete jacketed RC columns were modeled using four different uniaxial materials representing longitudinal steel, and unconfined, partially confined and fully confined concrete (Figure 4). Confined and unconfined concrete are modeled based on Mander et al. (1988), and fully confined concrete is modeled based on Campione et al. (2014). From OpenSees library, Concrete01, Concrete04 and Steel01 are used for unconfined concrete, confined concrete and steel materials, respectively.

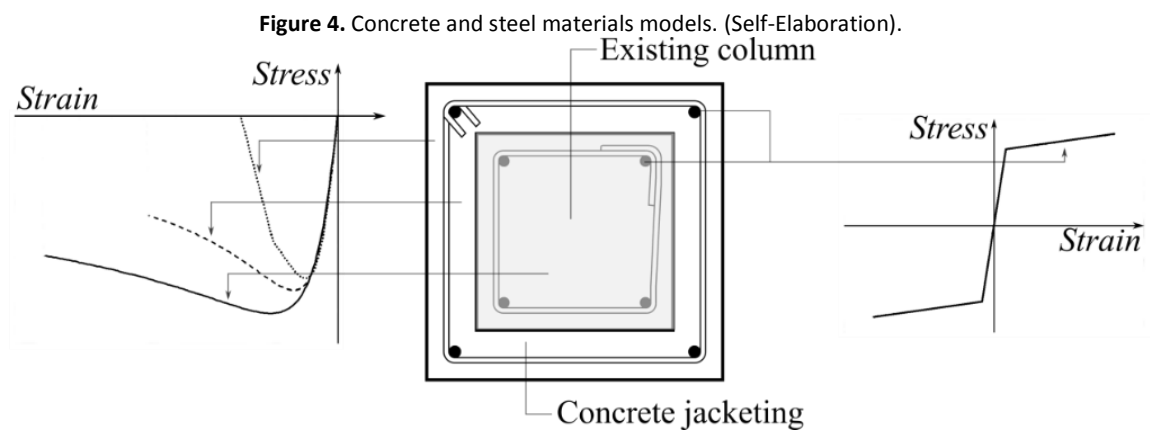

For the parametric study, the concrete jacketed RC column section shown in Figure 5 is used. The existing column of the jacketed column has a $300 \mathrm{~mm}$ square cross section. The longitudinal reinforcement includes four $14 \mathrm{~mm}$ diameter bars. Transverse reinforcement includes $8 \mathrm{~mm}$ diameter hoops with a vertical spacing of $200 \mathrm{~mm}$. Concrete cover from the center of the transverse steel is $30 \mathrm{~mm}$. Inside the jacket, the clear cover from exterior face of ties to edge of jacketed column was $10 \mathrm{~mm}$ to provide a minimum cover for the steel. The jacket had four $18 \mathrm{~mm}$ diameter longitudinal bars, and $8 \mathrm{~mm}$ ties spaced at $100 \mathrm{~mm}$. Yield strength for both longitudinal and transverse steel is $220 \mathrm{MPa}$ in the existing column, and $420 \mathrm{MPa}$ for both steels in the jacket. 


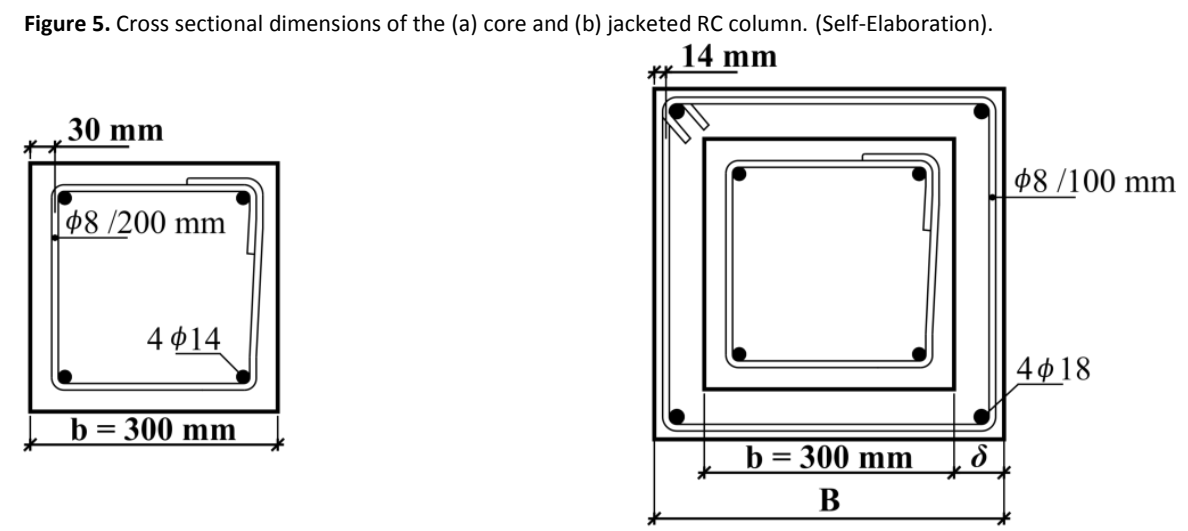

(a)

(b)

In the parametric study, compressive strength of concrete inside the jacket was kept constant as $25 \mathrm{MPa}$. The thickness of the jacket, $\delta$, and core concrete quality were selected as variables. The ratio of thickness of the jacket to existing column width, $\delta / b$, were chosen as $0.15,0.30$ and 0.50 . Core concrete inside the existing column had 10, 14, 16, 18, 20 and $25 \mathrm{MPa}$ compressive strength (Table 1.).

Axial load ratios (ALR) were calculated for the chosen lower and higher axial load levels, $N_{1}$ and $N_{2}$, respectively.

$$
A L R=\frac{N}{f_{c_{-} \text {core }} * b^{2}+f_{\text {c_jacket }} *\left(B^{2}-b^{2}\right)}
$$

where $f_{c_{-} \text {core }}$ and $f_{c_{-} \text {jacket }}$ are the concrete compressive strength for the core and jacket, respectively.

\begin{tabular}{ccccccccc}
\hline \multicolumn{10}{c}{ Table 1. Main parameters used for the analysis. } \\
$\begin{array}{c}\mathrm{b} \\
(\mathrm{mm})\end{array}$ & $\begin{array}{c}f_{\text {c_core }} \\
(\mathrm{MPa})\end{array}$ & $\begin{array}{c}f_{\text {c_jacket }}(\mathrm{MPa}) \\
(\mathrm{MP})\end{array}$ & $\begin{array}{c}\delta \\
\mathrm{B}\end{array}$ & $\begin{array}{c}N 1 \\
(\mathrm{~mm})\end{array}$ & $\begin{array}{c}N 2 \\
(\mathrm{kN})\end{array}$ & $\begin{array}{c}\text { ALR1 } \\
(\%)\end{array}$ & $\begin{array}{c}\text { ALR2 } \\
(\%)\end{array}$ \\
\hline 300 & 25 & 10 & 0.15 & 390 & 500 & 2000 & 20.4 & 81.5 \\
300 & 25 & 10 & 0.3 & 480 & 1000 & 3500 & 22.7 & 79.4 \\
300 & 25 & 10 & 0.5 & 600 & 1500 & 5500 & 19.6 & 71.9 \\
\hline 300 & 25 & 14 & 0.15 & 390 & 500 & 2000 & 17.8 & 71.1 \\
300 & 25 & 14 & 0.3 & 480 & 1000 & 3500 & 21.0 & 73.4 \\
300 & 25 & 14 & 0.5 & 600 & 1500 & 5500 & 18.7 & 68.7 \\
\hline 300 & 25 & 16 & 0.15 & 390 & 500 & 2000 & 16.7 & 66.8 \\
300 & 25 & 16 & 0.3 & 480 & 1000 & 3500 & 20.2 & 70.7 \\
300 & 25 & 16 & 0.5 & 600 & 1500 & 5500 & 18.3 & 67.2 \\
\hline 300 & 25 & 18 & 0.15 & 390 & 500 & 2000 & 15.8 & 63.0 \\
300 & 25 & 18 & 0.3 & 480 & 1000 & 3500 & 19.5 & 68.2 \\
300 & 25 & 18 & 0.5 & 600 & 1500 & 5500 & 17.9 & 65.7 \\
\hline 300 & 25 & 20 & 0.15 & 390 & 500 & 2000 & 14.9 & 59.7 \\
300 & 25 & 20 & 0.3 & 480 & 1000 & 3500 & 18.8 & 65.9 \\
300 & 25 & 20 & 0.5 & 600 & 1500 & 5500 & 17.5 & 64.3 \\
\hline 300 & 25 & 25 & 0.15 & 390 & 500 & 2000 & 13.1 & 52.6 \\
300 & 25 & 25 & 0.3 & 480 & 1000 & 3500 & 17.4 & 60.8 \\
300 & 25 & 25 & 0.5 & 600 & 1500 & 5500 & 16.7 & 61.1 \\
\hline
\end{tabular}


Axial stress-strain relationships were calculated for the fully confined concrete fibers with strengths varying from 10 to $25 \mathrm{MPa}$, and unconfined and partially confined concrete materials for varying values of $\delta / b$ using the developed computer code (Figure 6). Figure 6 shows that as the jacket thickness, $\delta$, increases the jacket provides better confinement for the existing column. As a result, the concrete strength increases and deformation capacity decreases. For example, when the $\delta / b$ ratio increases from 0.15 to 0.50 the confined concrete strength increases from $23.37 \mathrm{MPa}$ to $25.29 \mathrm{MPa}$ when the compressive strength of the existing column is $20 \mathrm{MPa}$. However, the failure strain is reduced from 0.027 to 0.021 when the $\delta / b$ ratio increased from 0.15 to 0.50 for $20 \mathrm{MPa}$ core concrete strength.

Axial load-moment interaction diagrams for concrete jacketed RC columns with different core concrete strengths are determined using the developed computer code. As shown in Figure 6, core concrete quality has virtually no effect on the response of concrete jacketed RC columns under low axial loads below the balance point. On the contrary, under higher axial loads the axial load and flexure capacity of concrete jacketed RC columns increases with increasing core concrete quality. Figure 6 also shows that $\delta / b$ ratio has a significant effect on the overall axial load and moment strength of the jacketed columns. For example, at balanced point, moment and axial load capacity of jacketed column are 267.8 $\mathrm{kNm}$ and $1649.2 \mathrm{kN}$, respectively, for $\delta / b=0.15$ when the core concrete strength is $25 \mathrm{MPa}$. The moment and axial load capacity are $789.3 \mathrm{kNm}$ and $4070.2 \mathrm{kN}$ at balanced point for the jacketed column with $25 \mathrm{MPa}$ core concrete strength and $\delta / b=0.50$.

Figure 6. Jacket and core concrete material models and axial load-moment interaction diagrams of concrete jacketed RC columns with varying core concrete strengths. (Self-Elaboration).
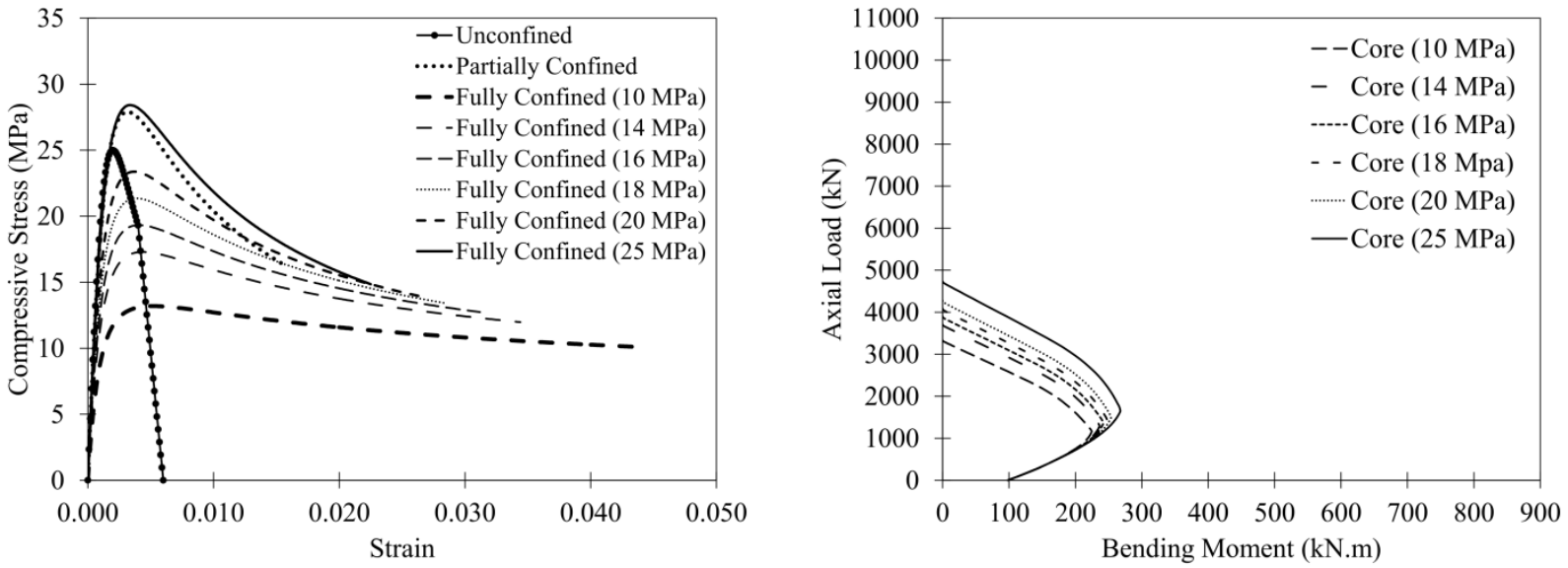

(a) $\frac{\delta}{b}=0.15$
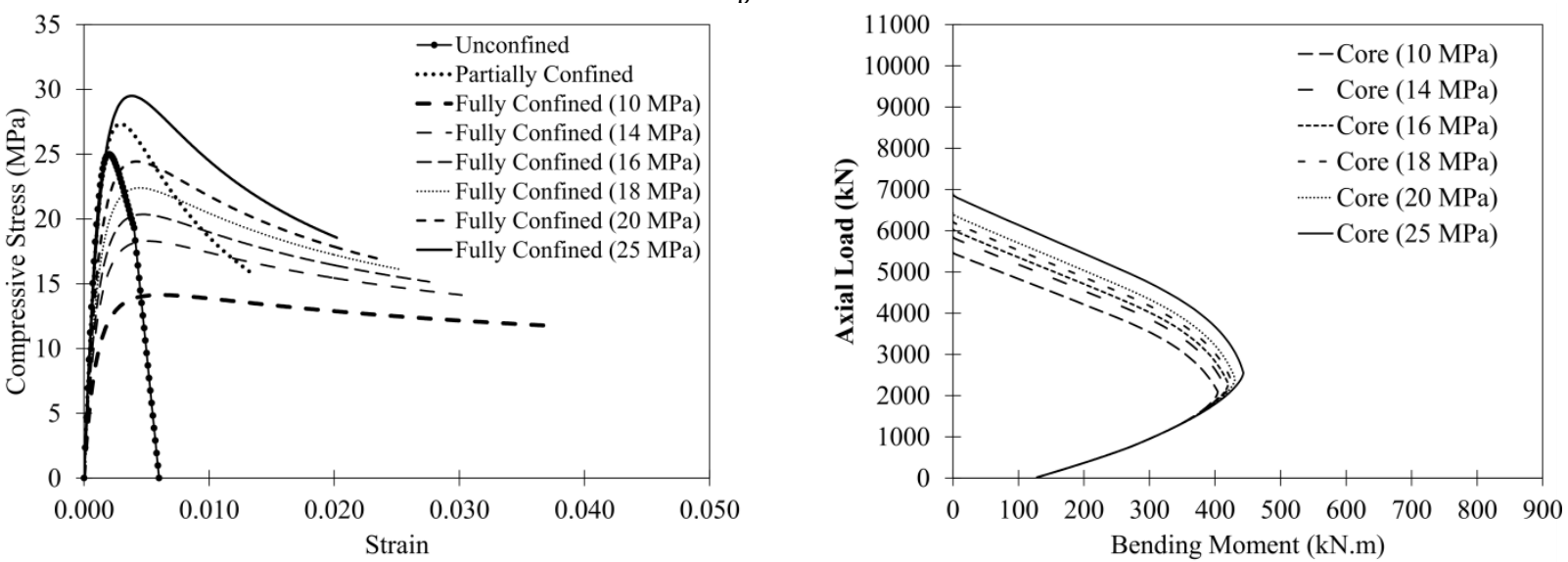

(b) $\frac{\delta}{b}=0.30$ 

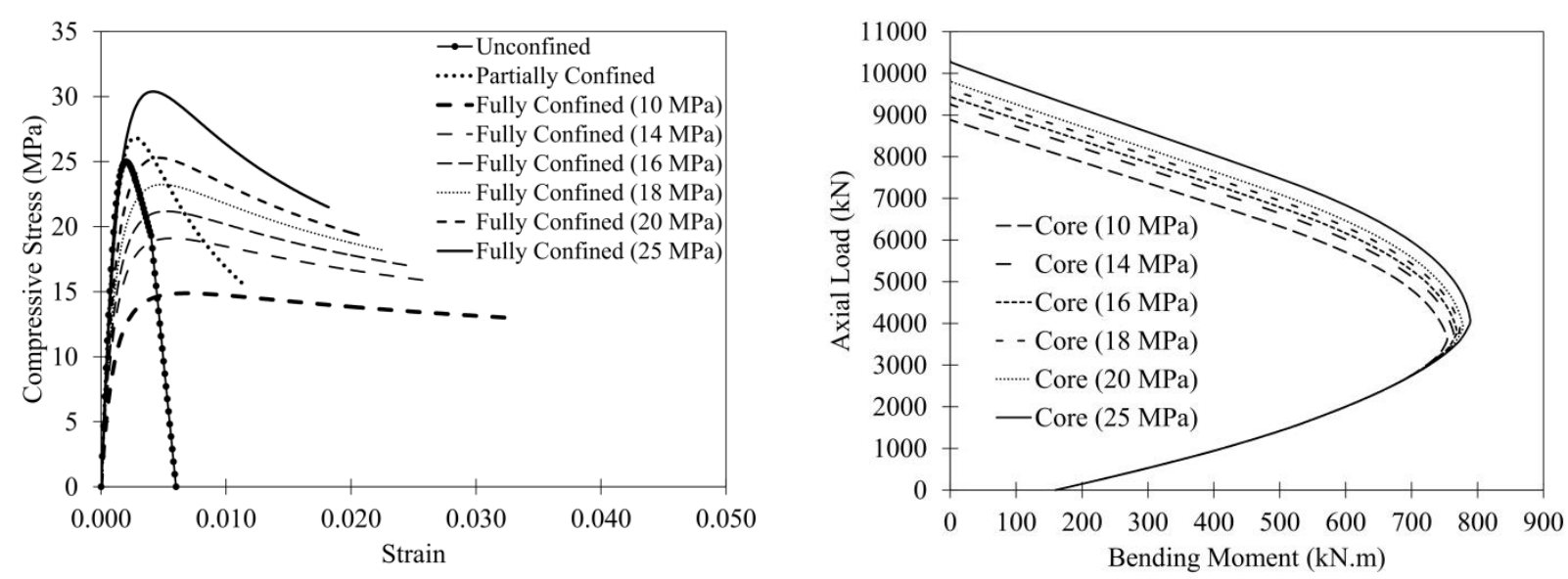

(c) $\frac{\delta}{b}=0.50$

Moment curvature relationships were calculated to have a better understanding of response of concrete jacketed RC columns at lower and higher axial load levels (Figure 7). Lower axial load $\left(N_{1}\right)$ levels were selected as 500,1000 and $1500 \mathrm{kN}$ below the balanced axial load $\left(N_{b}\right)$ for $\delta / b=0.15,0.30$ and 0.50 , respectively. Higher axial load $\left(N_{2}\right)$ levels were selected as 2000, 3500 and $5500 \mathrm{kN}$ above the balanced point in the axial load-moment interaction diagram for $\delta / b=0.15,0.30$ and 0.50 , respectively. Figure 7 shows that the core concrete quality has virtually no effect on the flexural response of concrete jacketed RC columns subjected to low axial forces for all jacket thicknesses or $\delta / b$ ratios. This is mainly because the natural axis is typically inside the jacket and most of existing column or core concrete is in tension and does not contribute to the flexural strength. On the contrary, core concrete quality has a significant effect on the bending response of concrete jacketed RC columns subjected to constant high axial forces above the balance point. As the core concrete quality increases the flexural response of concrete jacketed RC columns improve in terms of both flexural strength and curvature ductility capacity.

As the $\delta / b$ ratio increases, the distance between adjacent longitudinal bars in the jacket also increases, therefore effectively confined concrete area inside jacket decreases. For this reason, as shown in Figure 7, by increasing $\delta / b$ ratio the ductility of concrete jacketed RC columns also decreases. For example, when the $\delta / b$ ratio increases from 0.15 to 0.50 the ductility of concrete jacketed RC columns decreases from 0.218 to 0.091 for lower axial load levels and compressive strength of the core column is $25 \mathrm{MPa}$. In addition, for higher axial load levels the ductility of concrete jacketed RC columns decreases from 0.074 to 0.032 when the $\delta / b$ ratio increases from 0.15 to 0.50 and core concrete strength is $25 \mathrm{MPa}$.

The moment strength increases with increasing $\delta / b$ ratio because of the increase in the amount of higher strength concrete inside the jacket. Moreover, the effect and contribution of jacket concrete on the flexural response of concrete jacketed RC columns may be reduced due to potential slip along the interface between the new and existing concrete. Therefore, the effect of the concrete strength of existing column is likely to become more evident on the response of concrete jacketed RC columns when the axial load magnitude is high and interface slip is also taken into account.

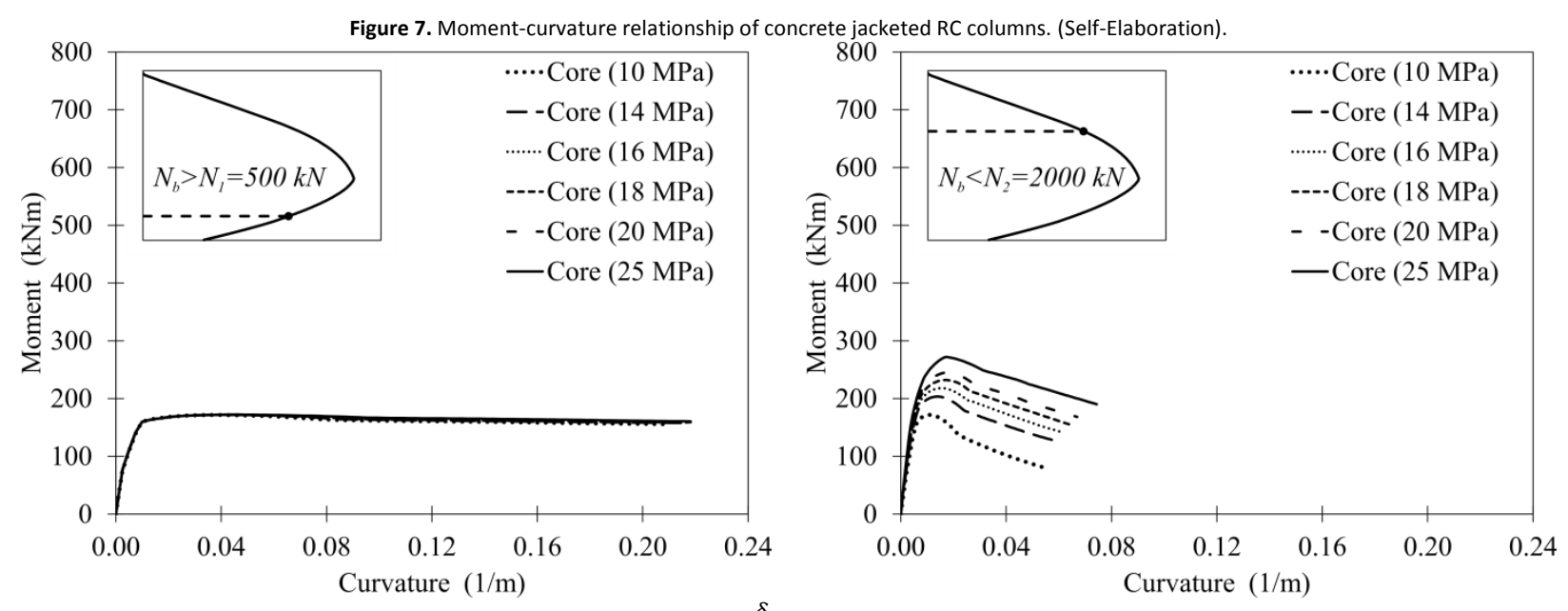

(a) $\frac{\delta}{b}=0.15$ 

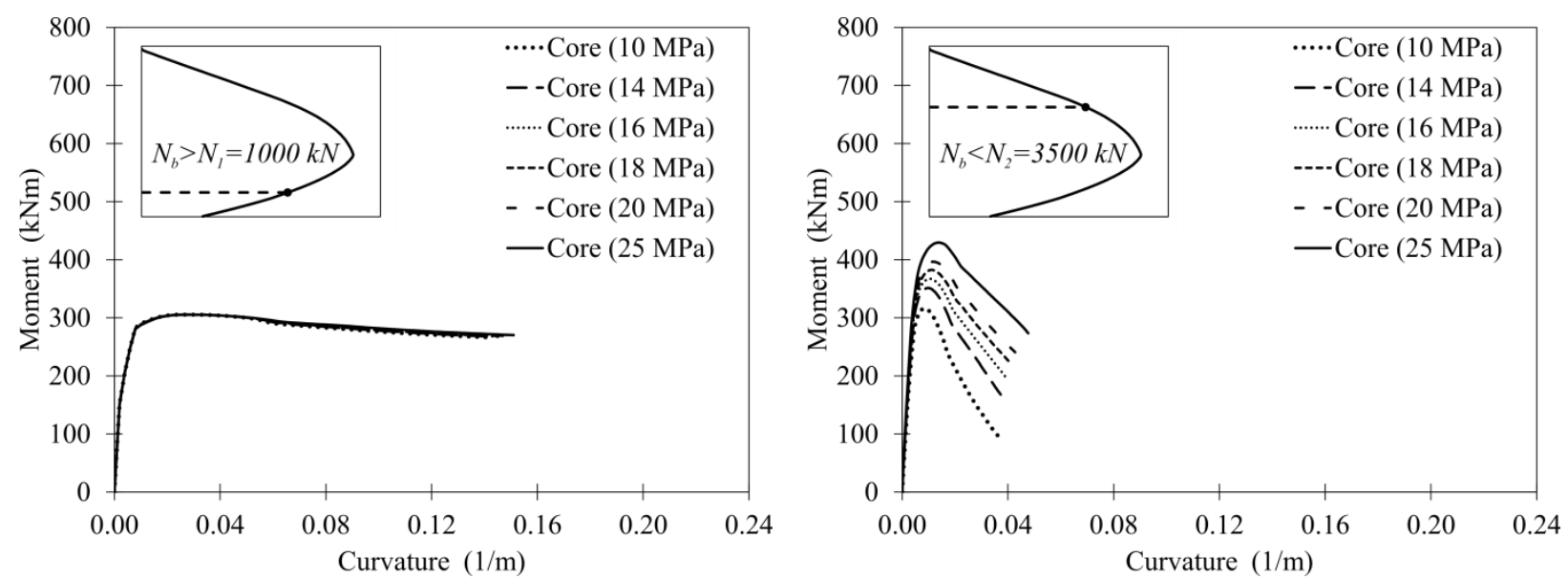

(b) $\frac{\delta}{b}=0.30$
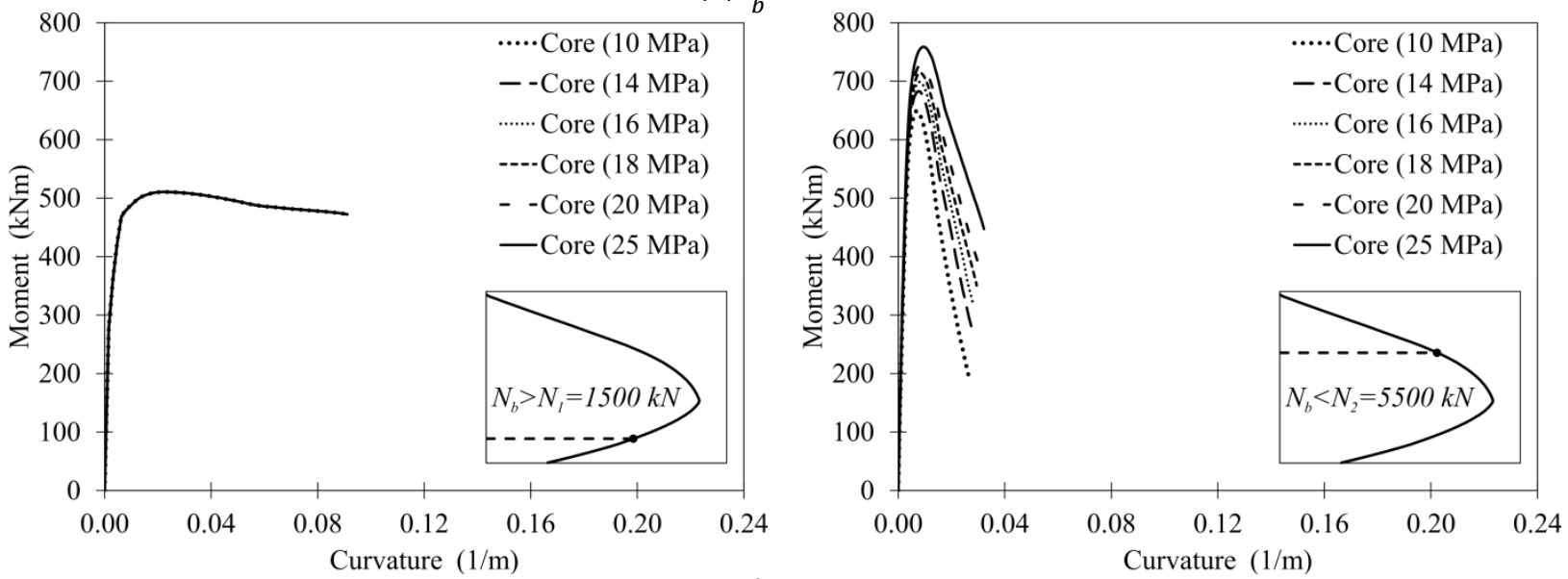

(c) $\frac{\delta}{b}=0.50$

Conclusions

Based on the results of the numerical simulations and comparison with the experimental response of concrete jacketed $\mathrm{RC}$ columns the following conclusions are reached. It was determined that the effect of concrete quality of the existing column on response of jacketed column highly depend on the axial load level. As could be seen clearly (Figures 9 and 10), the existing column's concrete quality has no effect on concrete jacketed RC column behavior when the axial load is less than the balanced axial load $\left(N<N_{b}\right)$. However, when the applied axial load is larger than the balanced axial load $\left(N>N_{b}\right)$ the concrete strength of existing column significantly increases the strength of concrete jacketed RC column. Moreover, and as expected, the response of concrete jacketed RC column has a ductile behavior when $N<N_{b}$, and more brittle behavior when $N>N_{b}$. Therefore, this study demonstrates that the concrete quality of the existing column has no influence on ductile behavior of concrete jacketed RC column under lower axial loads while under higher axial load core concrete increases the strength but reduces the ductility.

Acknowledgment

Part of this research was conducted during the first author's one-year visit to the Ohio State University. This visit was funded by The Scientific and Technological Research Council of Turkey (TUBITAK), which is greatly acknowledged.

References

Achillopoulou, D. V. (2017). Investigation of load transfer along interfaces of jacketed square columns. Structural Engineering and Mechanics: An International Journal, 63(3), 293-302.

Bousias, S. N., Biskinis, D., Fardis, M. N., \& Spathis, A. L. (2007). Strength, stiffness, and cyclic deformation capacity of concrete jacketed members. ACl Structural Journal, 104 (5), 521-531

Campione, G., Fossetti, M., Giacchino, C., \& Minafò G (2014). RC columns externally strengthened with RC jackets. Materials and Structures, 47 (10), 1715-1728. 
Celebi, E., Aktas, M., Caglar, N., Ozocak, A., Kutanis, M., Mert, N., \& Ozcan, Z. (2013). October 23, 2011 Turkey/Van-Ercis earthquake: structural damages in the residential buildings. Natural Hazards, 65 (3), 2287-2310.

Chai, Y. H., Priestley, M. J. N., \& Seible, F. (1991). Flexural retrofit of circular reinforced concrete bridge columns by steel jacketing. Report No. SSRP, San Diego, University of California.

Chaulagain, H., Rodrigues, H., Spacone, E., \& Varum, H. (2015). Assessment of seismic strengthening solutions for existing low-rise RC buildings in Nepal. Eartquakes and Structures: An Int'l Journal, 8 (3), 511-539.

Di Carlo, F., Meda, A., \& Rinaldi, Z. (2017). Numerical cyclic behaviour of un-corroded and corroded RC columns reinforced with HPFRC jacket. Composite Structures, $163,432-443$.

Elenas, A. (2003). Athens earthquake of 7 September 1999: Intensity measures and observed damages. ISET Journal of Earthquake Technology: Technical Note, 40 (1), 77-97.

Ersoy, U., Tankut, T., \& Suleiman, R. (1993). Behavior of jacketed columns. ACl Structural Journal, 90 (3), $288-293$.

Hosseini, A., Khaloo, A. R., \& Fadaee, S. (2005). Seismic performance of high-strength concrete square columns confined with carbon fiber reinforced polymers (CFRPs). Canadian Journal of Civil Engineering, 32(3), 569-578.

Júlio, E., \& Branco, F. (2008). Reinforced concrete jacketing-interface influence on cyclic loading response. ACl Structural Journal, 105 (4), $471-477$.

Juntanalikit, P., Jirawattanasomkul, T., \& Pimanmas, A. (2016). Experimental and numerical study of strengthening non-ductile RC columns with and without lap splice by Carbon Fiber Reinforced Polymer (CFRP) jacketing. Engineering Structures, 125, 400-418.

Kawashima, K., Aydan, O., Aoki, T., Kishimoto, I., Matsui, T., Sakuta, J., Takahashi, N., Teodori, S. P., \& Yashima, A. (2010). Damage of 2009 L'Aquila, central Italy earthquake. Journal of Earthquake Engineering, 14 (6), 816-841.

Lekkas, E. (2001). The Athens earthquake (7 September 1999): intensity distribution and controlling factors. Engineering Geology, 59, $297-311$.

MATLAB. (2011), Version 2011a. Natick, Massachusetts: The MathWorks Inc., http://www.mathworks.com.

Mander, J. B., Priestley, J. N., \& Park, R. (1988). Theoretical stress-strain model for confined concrete. Journal of Structural Engineering, 114 (8), 18041825.

McKenna, F., Fenves, G. L., \& Scott, M. H. (2004). Open system for earthquake engineering simulation (OpenSees). Pacific Earthquake Engineering Research Center, University of California, Berkeley, CA.

Nakahara, H., \& Yin, H. (2018). Self-Centering Capacity of a Structural Frame Composed of Steel-Jacketed Concrete Columns and Steel Beams. Structures, $14,409-415$

Rodriguez, M., \& Park, R. (1994). Seismic load tests on reinforced concrete columns strengthened by jacketing. Structural Journal, 91 (2), $150-159$.

Rupp, J., Sezen, H., \& Chaturvedi, S. (2014). Axial Behavior of Steel-Jacketed Concrete Columns. Steel and Composite Structures, 16 (1), $61-77$.

Sarnoa, L. D., Elnashai, A. S., \& Manfredi, G. (2011). Assessment of RC columns subjected to horizontal and vertical ground motions recorded during the 2009 L'Aquila (Italy) earthquake. Engineering Structures, 33 (5), 1514-1535.

Sezen, H., Whittaker, A. S., Elwood, K. J., \& Mosalam, K. M. (2003). Performance of reinforced concrete buildings during the August 171999 Kocaeli, Turkey earthquake, and seismic design and construction practice in Turkey. Engineering Structures, 25 (1), $103-114$.

Sezen, H., \& Miller, E. (2007). Retrofit of circular reinforced concrete columns using FRP, steel and concrete jackets. Structures Congress: New Horizons and Better Practices, Long Beach, California, USA.

Thermou, G. E., Pantazopoulou, S. J., \& Elnashai, A. S. (2007). Flexural behavior of brittle RC members rehabilitated with concrete jacketing. Journal of Structural Engineering, 133(10), 1373-1384.

Thermou, G. E., Papanikolaou, V. K., \& Kappos, A. J. (2014). Flexural behaviour of reinforced concrete jacketed columns under reversed cyclic loading. Engineering Structures, 76, 270-282.

Vandoros, K. G., \& Dritsos, S. E. (2008), Concrete jacket construction detail effectiveness when strengthening RC columns. Construction and Building Materials, 22 (3), 264-276. 